\title{
13. BIOSTRATIGRAPHIC SUMMARY OF THE JAPAN TRENCH TRANSECT, LEGS 56 AND 57, DEEP SEA DRILLING PROJECT
}

\author{
John A. Barron, ${ }^{1}$ Howard E. Harper, Jr., ${ }^{2}$ Gerta Keller, ${ }^{3}$ Richard A. Reynolds, ${ }^{4}$ \\ Toyusaburo Sakai, ${ }^{5}$ Bernard L. Shaffer, ${ }^{6}$ and Peter R. Thompson ${ }^{7}$
}

\section{INTRODUCTION}

During the Japan Trench Transect (DSDP Legs 56 and 57, September-December 1977), 377 cores from 15 holes at 7 DSDP sites were taken (Figure 1, Table 1). The DSDP sites represent water depths of 1552 meters (Hole 438) to 5986 meters (Site 434), from the continental slope (Sites 434, 435, 438-441) to the ocean basin (Site 436). (No sediment was recovered at Site 437.) Predominantly Miocene to Quaternary sediment was recovered, although some Cretaceous sediment was cored at Sites 436 and 439 and possible uppermost Oligocene sediment at Site 438 .

Sediments recovered during the Japan Trench Transect provide excellent Neogene siliceous reference sections for the northwest Pacific from an open ocean environment (Site 436) to an upper slope environment (Site 438). The location of the transect near the confluence of the cold-water Oyashio Current and the warmwater Kuroshio Current results in a mixture of high- and low-latitude microfossil assemblages throughout the Neogene and allows correlation of the various high- and low-latitude zonations that are used in the North Pacific. Diatoms and radiolarians are the most abundant, continuously present microfossils, and provide the best biostratigraphic control. Planktonic foraminifers and calcareous nannofossils also contribute important biostratigraphic and paleoclimatic information. Benthic foraminifers are useful for paleobathymetric interpretation and date the upper Oligocene and Upper Cretaceous sequences that contain no planktonic faunas or floras.

Planktonic microfossil zonations used for Legs 56 and 57 are modified from zonations previously applied to the North Pacific. The diatom zonation is essentially that of Koizumi (1975), although new subzones and an additional zone have been added (Barron, this volume) to allow additional refinement at this latitude in the northwest Pacific. Generally, the subzones are defined by diatom events that have been tied to the paleomag-

\footnotetext{
1 U.S. Geological Survey, Menlo Park California.

${ }^{2}$ Atlantic Richfield Company, Dallas, Texas.

${ }^{3}$ Department of Geology, Stanford University, Stanford, California.

${ }^{4}$ Department of Geology, Rice University, Houston, Texas.

${ }^{5}$ Institute of Geology and Paleontology, Tohuku University, Sendai, Japan.

${ }^{6}$ Gulf Research and Development Company, Houston, Texas.

${ }^{7}$ Lamont-Doherty Geological Observatory, Palisades, New York.
}

netic record and/or have been useful in other areas of the North Pacific.

The radiolarian zones of Foreman (1975) are used with slight modification (Reynolds, this volume) for the upper Miocene to Recent. Reynolds (this volume) has established a new zonation for the lower and middle Miocene, using radiolarian events that appear to have widespread application.

The nannofossil zonation of Bukry (1975) has been employed for the Miocene and Pliocene, and a modified version of Gartner's (1977) zonation has been used for the Pleistocene (Shaffer, this volume).

Planktonic foraminifers are tied to the standard zonation of Blow (1969), using mid- to high-latitude foraminiferal datums by Keller (this volume) and Thompson (this volume).

These microfossil zonations are correlated to each other and to the absolute time scale in Figure 2. The paleomagnetic time scale is that of LaBrecque and others (1977). The diatom zones and subzones are tied to this scale following Koizumi $(1975,1977)$, Burckle and Opdyke (1977), Burckle (1978), and Burckle (written communication, 1978). Additional ties are estimated by Barron (this volume). Pleistocene and Pliocene radiolarian zones are tied to the paleomagnetic record, using the results of Hays (1970). Additional radiolarian correlations are interpreted from Ryan and others (1974). A combination of Gartner $(1973,1977)$, Bukry (1975), and Ryan and others (1974) is used to assign absolute ages to the nannofossil zonation. Planktonic foraminiferal datum levels are from Keller $(1978,1979)$ and Thompson (1978). Ryan and others' (1974) correlation of Blow's (1969) zonation to the paleomagnetic scale is also employed.

The Pliocene/Pleistocene boundary is placed at the top of the Olduvai Event, at about 1.6 m.y.B.P., following Haq and others (1977). The boundary between the Miocene and Pliocene is that of Cita (1975) and Van Couvering and others (1976) in the lowermost reversed event of the Gilbert Paleomagnetic Epoch (approximately 5.0 m.y.B.P.). Other age assignments follow Ryan and others (1974): lower Pliocene/upper Pliocene - lowermost Gauss, 3.3 m.y.B.P.; upper Miocene/middle Miocene - lower Epoch 11, 11.35 m.y.B.P.; lower Miocene/middle Miocene - lower part of the upper reversed event of Epoch 16, about 15.6 m.y.B.P.; Miocene/Oligocene - upper part of Epoch 22, about 22.5-23.0 m.y.B.P. Absolute ages of these boundaries have been adjusted to fit the paleomagnetic time scale of LaBrecque and others (1977). 


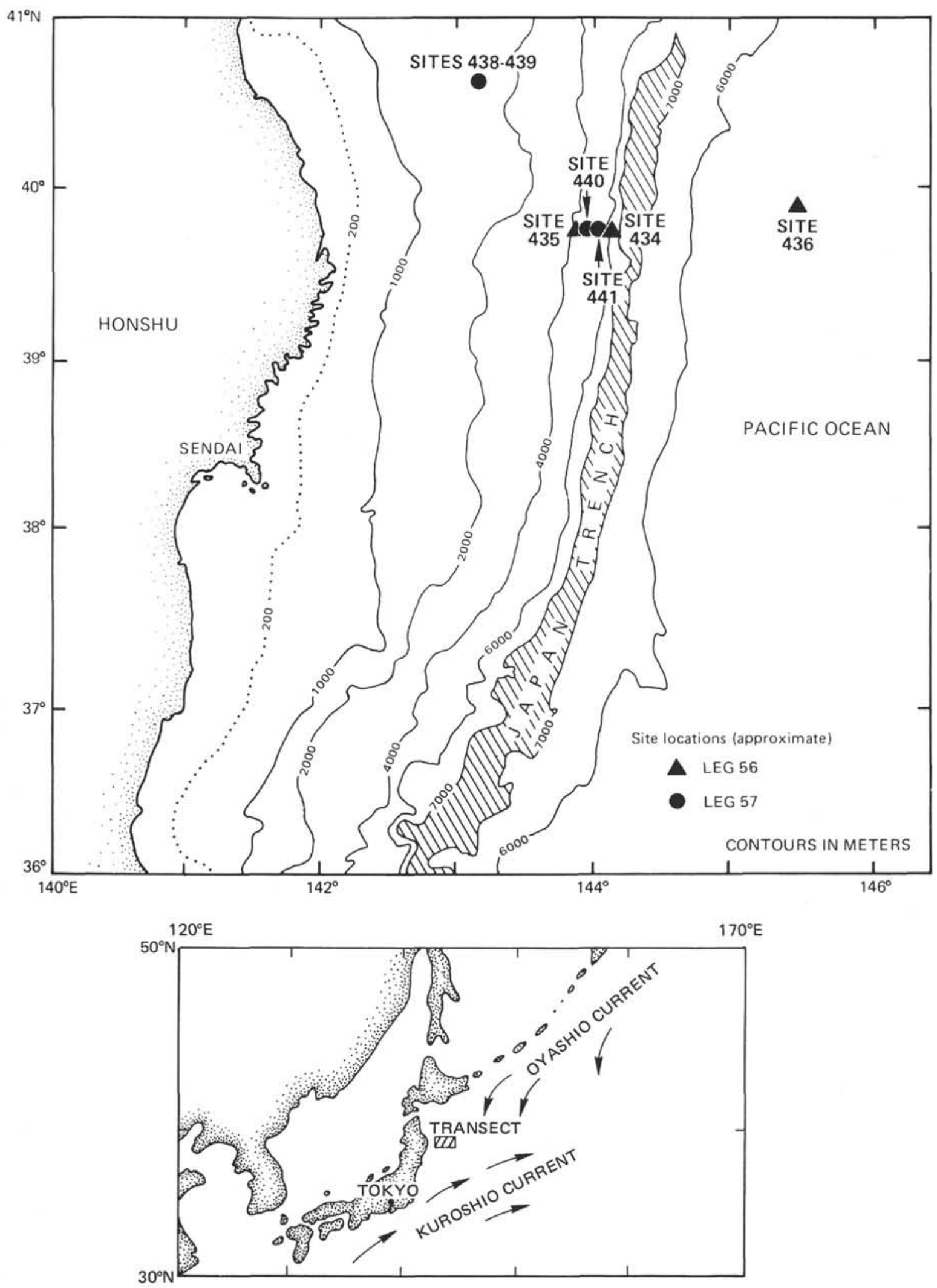

Figure 1. Location of the Japan Trench Transect (DSDP Legs 56 and 57) off northeast Japan near the confluence of the warm-water Kuroshio Current and the cold-water Oyashio Current. Upper map is an enlargement of the Transect area. 
TABLE 1

Japan Trench Transect Coring Summary

\begin{tabular}{|c|c|c|c|c|c|c|}
\hline Hole & Latitude & Longitude & $\begin{array}{l}\text { Depth below } \\
\text { Sea Level } \\
\text { (m) }\end{array}$ & $\begin{array}{l}\text { Penetration of } \\
\text { Cored Section } \\
\text { (m) }\end{array}$ & $\begin{array}{l}\text { Total Core } \\
\text { Recovery } \\
\text { (m) }\end{array}$ & $\begin{array}{c}\text { Oldest } \\
\text { Sediment Cored }\end{array}$ \\
\hline \multicolumn{7}{|c|}{ Leg 57} \\
\hline $\begin{array}{l}438 \\
438 \mathrm{~A} \\
438 \mathrm{~B} \\
439 \\
440 \\
440 \mathrm{~A} \\
440 \mathrm{~B} \\
441 \\
441 \mathrm{~A} \\
441 \mathrm{~B}\end{array}$ & $\begin{array}{l}40^{\circ} 37.75^{\prime} \mathrm{N} \\
40^{\circ} 37.79^{\prime} \mathrm{N} \\
40^{\circ} 37.80^{\prime} \mathrm{N} \\
40^{\circ} 37.61^{\prime} \mathrm{N} \\
39^{\circ} 44.13^{\prime} \mathrm{N} \\
39^{\circ} 44.13^{\prime} \mathrm{N} \\
39^{\circ} 44.13^{\prime} \mathrm{N} \\
39^{\circ} 45.05^{\prime} \mathrm{N} \\
39^{\circ} 45.05^{\prime} \mathrm{N} \\
39^{\circ} 45.08^{\prime} \mathrm{N}\end{array}$ & $\begin{array}{l}143^{\circ} 13.90^{\prime} \mathrm{E} \\
143^{\circ} 14.15^{\prime} \mathrm{E} \\
143^{\circ} 14.80^{\prime} \mathrm{E} \\
143^{\circ} 18.63^{\prime} \mathrm{E} \\
143^{\circ} 55.74^{\prime} \mathrm{E} \\
143^{\circ} 55.74^{\prime} \mathrm{E} \\
143^{\circ} 55.74^{\prime} \mathrm{E} \\
144^{\circ} 04.55^{\prime} \mathrm{E} \\
143^{\circ} 04.59^{\prime} \mathrm{E} \\
144^{\circ} 04.60^{\prime} \mathrm{E}\end{array}$ & $\begin{array}{l}1552 \\
1558 \\
1564 \\
1656 \\
4507 \\
4507 \\
4507 \\
5655 \\
5646 \\
5640\end{array}$ & $\begin{array}{r}109.5 \\
878.0 \\
1040.7 \\
1157.5 \\
73.0 \\
139.5 \\
814.0 \\
293.0 \\
662.0 \\
687.0\end{array}$ & $\begin{array}{r}81.9 \\
555.3 \\
192.6 \\
163.0 \\
50.4 \\
33.5 \\
401.9 \\
16.6 \\
19.7 \\
5.5\end{array}$ & $\begin{array}{l}\text { late Pliocene } \\
\text { early Miocene } \\
\text { early Miocene } \\
\text { late Cretaceous } \\
\text { Pleistocene } \\
\text { Pleistocene } \\
\text { late Miocene } \\
\text { early Pliocene } \\
\text { late Miocene } \\
\text { late Miocene }\end{array}$ \\
\hline \multicolumn{7}{|c|}{ Leg 56} \\
\hline $\begin{array}{l}434 \\
434 \mathrm{~A} \\
434 \mathrm{~B} \\
435 \\
435 \mathrm{~A} \\
436\end{array}$ & $\begin{array}{l}39^{\circ} 44.8^{\prime} \mathrm{N} \\
39^{\circ} 44.8^{\prime} \mathrm{N} \\
39^{\circ} 44.9^{\prime} \mathrm{N} \\
39^{\circ} 44.09^{\prime} \mathrm{N} \\
39^{\circ} 44.10^{\prime} \mathrm{N} \\
39^{\circ} 55.96^{\prime} \mathrm{N}\end{array}$ & $\begin{array}{l}144^{\circ} 06.1^{\prime} \mathrm{E} \\
144^{\circ} 06.1^{\prime} \mathrm{E} \\
144^{\circ} 06.1^{\prime} \mathrm{E} \\
143^{\circ} 47.53^{\prime} \mathrm{E} \\
143^{\circ} 47.59^{\prime} \mathrm{E} \\
145^{\circ} 33.47^{\prime} \mathrm{E}\end{array}$ & $\begin{array}{l}5986 \\
5986 \\
5986 \\
3401 \\
3401 \\
5240\end{array}$ & $\begin{array}{l}301.0 \\
160.5 \\
637.5 \\
150.5 \\
244.5 \\
397.5\end{array}$ & $\begin{array}{r}55.3 \\
14.0 \\
64.1 \\
78.4 \\
45.2 \\
240.8\end{array}$ & $\begin{array}{l}\text { late Miocene } \\
\text { early Pliocene } \\
\text { late Miocene } \\
\text { early Pliocene } \\
\text { early Pliocene } \\
\text { early Cretaceous }\end{array}$ \\
\hline
\end{tabular}

\section{SITES 438, 439 - UPPER SLOPE}

\section{Site $\mathbf{4 3 8}$}

Site 438 is located on the upper continental slope about $130 \mathrm{~km}$ off northeast Japan. Three holes were drilled at this site: Holes 438, 438A, and 438B, reaching depths of 110 meters, 878 meters, and 1040 meters, respectively. The oldest sediment recovered was lower Miocene.

The 110 meters of upper Pliocene to Pleistocene sediments penetrated in Hole 438 consists of diatomaceous ooze and silty diatomaceous clay with erratic pebbles. Hole $438 \mathrm{~A}$ cored through a section of relatively uniform diatomaceous ooze, diatomaceous clay, and diatomaceous claystone ranging from the lower Miocene to the Pleistocene. Hole 438B recovered lower Miocene to upper Miocene diatomaceous claystone and siltstone. Volcanic detritus is found throughout the Site 438 sections.

Diatoms provided the best biostratigraphic control; radiolarians also offered good control. Calcareous plankton ranges from abundant in upper Pleistocene sediments to common or few in lower Pleistocene and Pliocene sediments. The Miocene sediments are generally poor in calcareous fossils.

The biostratigraphic zonations of Holes 438, 438A, and 438B are illustrated in Figures 3, 4, and 5, respectively. A good correlation exists between the upper Pliocene to Pleistocene sediments in Holes 438 and 438 A and between lower Miocene to middle Miocene sediments in Holes 438A and 438B. Diatom data revealed two hiatuses in the Miocene sections of Hole 438A (Barron, this volume). One hiatus occurs in the upper Miocene within Core $42(450 \mathrm{~m})$, and the second occurs in the middle Miocene between Cores 65 and 66 $(680 \mathrm{~m})$. The missing record in each of these hiatuses is estimated to be about one million years.
In Hole 438A, paleomagnetic studies identify the Matuyama/Gauss Epoch boundary at 120 meters, the Gauss/Gilbert Epoch boundary at 210 meters, and the top of the "c" Event of the Gilbert at 310 meters (Hall and Smeltzer, this volume). This paleomagnetic stratigraphy is in close agreement with the microfossil stratigraphy (Figures 3, 4, and 5).

Benthic foraminifers indicate that Site 438 rose to its present depth (about $1500 \mathrm{~m}$ ) in the late Pliocene from a late Miocene-Pliocene depth of about 2000 meters.

\section{Site 439}

Site 439 was drilled about $5 \mathrm{~km}$ east of Site 438 . Biostratigraphic correlation with Site 438 was established by spot cores, and the lower Miocene section was continuously cored. This section is represented by approximately 138 meters of sediments (Cores 6-21). Two distinct lithologies are present in this interval; the upper 55 meters (Cores 439-6-439-11) consists of olive gray diatomaceous claystone and turbidite layers, and the lower 83 meters (Cores 439-12-439-21) is dominantly olive black silty claystone and turbidites. Diatoms and radiolarians are generally present at Site 439 , whereas calcareous plankton are extremely rare.

Spot cores taken at 498, 555, 649, and 745 meters establish a good biostratigraphic correlation with Site 438 , based primarily on diatom and radiolarian biostratigraphy. Cores 1 and 2 at Site 439 are late Miocene and correspond to Cores 35 through 47 in Hole 438A. Core $439-3$ is middle Miocene and is coeval with Cores 61 and 62 in Hole 438A and Core 2 in Hole 438B. Core 439-4, also middle Miocene, correlates with Cores 68 to 83 in Hole 438A. Cores 439-5 and 439-6 at the top of the continuously cored section correspond to Cores 83 and 84 in Hole $438 \mathrm{~A}$ and encompass the early to middle Miocene boundary (Figure 3). 


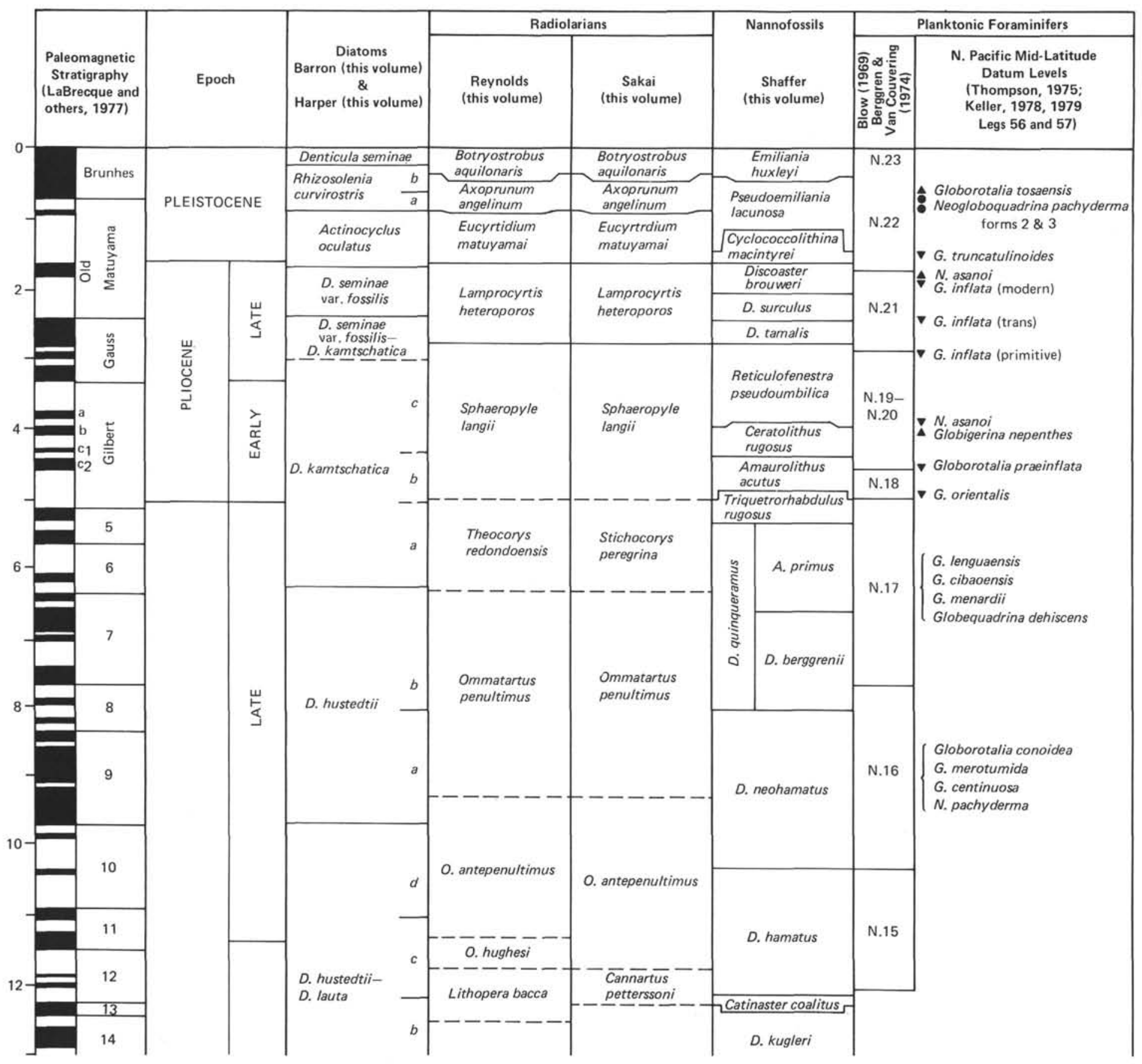




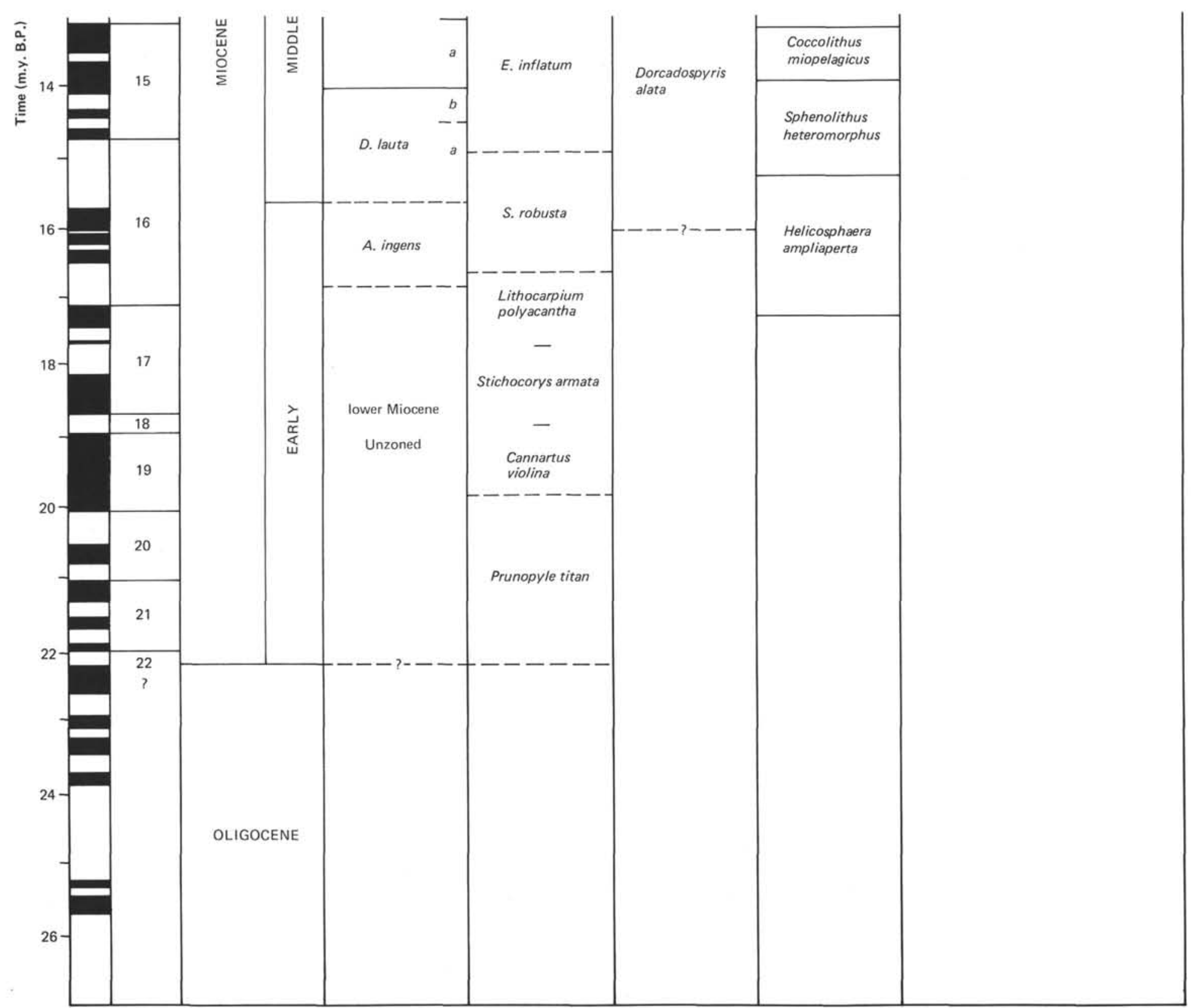

Figure 2. Correlation of the microfossil zones of Legs 56 and 57 with the geologic time scale. (Paleomagnetic time scale is that of LaBrecque and others [1977]. Epoch boundaries are assigned after Ryan and others [1974], Cita [1975], Van Couvering and others [1976], and Haq and others [1977].) 


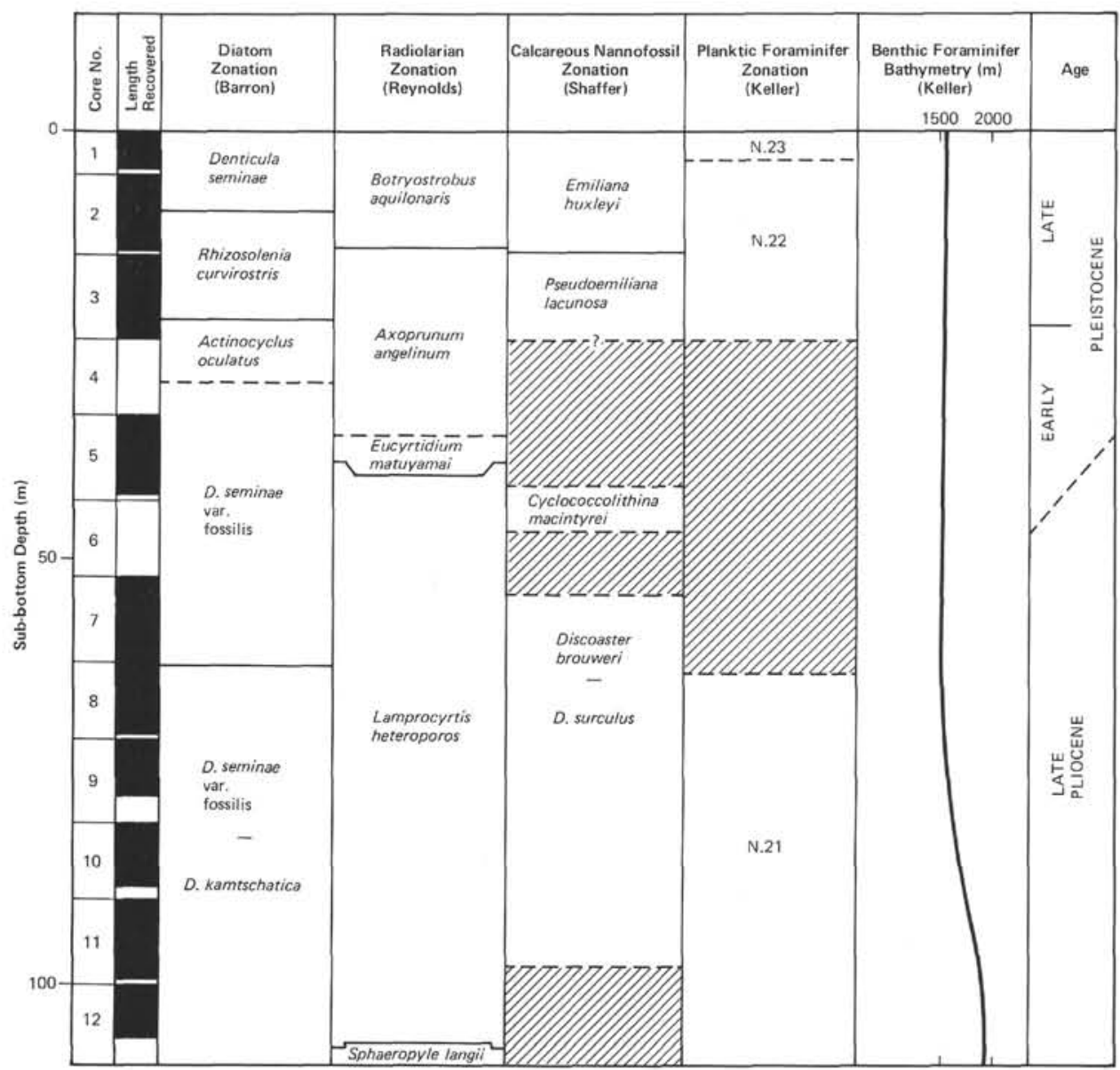

Figure 3. Planktonic microfossil biostratigraphy and generalized paleobathymetry of Site 438, Hole 438. (Solid area represents recovered intervals; cross-hatched area represents intervals that could not be zoned.)

The early Miocene record is preserved in Cores 439-6 to $439-21$ (Figure 6). A hiatus is recognized between Cores 439-11 and 439-13 (915-925 m), based on diatoms (Barron, this volume) and radiolarians (Reynolds, this volume). Diatom stratigraphy indicates that the lower part of the Actinocyclus ingens Zone, which is present in Hole 438B, is missing (Barron, this volume). Radiolarian stratigraphy indicates the absence or partial representation of the Lithocarpium polyacantha, Stichocorys armata, and Cannartus violina zones, which are present in Hole 438B (Figures 5 and 6) (Reynolds, this volume).

Between Cores 439-24 and 439-32, only rare diatoms, very small coccoliths, and reworked Cretaceous radiolarians were recovered. However, diverse assemblages of shallow-water benthic foraminifers were recovered between Cores 439-22 and 439-25 which indicate latest Oligocene age and deposition in shelfal environment. Very rare benthic foraminifers were recovered between Cores 439-26 and 439-36, including the 33-meter section of conglomerate. These isolated specimens preclude age assignment. However, a K-Ar date of $23.4 \pm 5.5$ m.y. (Moore and Dalrymple, this volume) and an argon date of $22.2 \pm 1.2 \mathrm{~m} . \mathrm{y}$. (Yanagisawa and others, this volume) indicate that this unit is of latest Oligocene or earliest Miocene age.

Very poorly preserved arenaceous benthic foraminifers of Late Cretaceous age were recovered from the black fissile shale which unconformably underlies the conglomerate. This benthic assemblage indicates that deposition occurred in a deep bathyal environment $(4000$ $\mathrm{m}+$ ).

\section{SITE 435 - UPPER SLOPE}

Site 435 was located on the upper slope, seaward from Sites 438 and 439, and sampled an almost complete section of Pleistocene and Pliocene diatomaceous ooze and diatomaceous claystone. The claystone contains excellent diatom floras and radiolarian faunas but only fair foraminiferal faunas, possibly owing to the depth of Site 435 near the CCD (about $3500 \mathrm{~m}$ in the area) (Figure 7).

Poor biostratigraphic control at the bottom of Hole 435 A prevented an accurate basal age determination, but the microfossil assemblages are probably close to the Miocene/Pliocene boundary. Foraminiferal faunas indicate that about 500 meters of uplift occurred during deposition of this section, and a prominent cooling is in- 




Figure 4. Planktonic microfossil biostratigraphy and generalized paleobathymetry of Site 438, Hole 438A. (Solid area represents recovered intervals; cross-hatched area represents intervals that could not be zoned.)

dicated during the late Pleistocene (Thompson, this volume).

\section{SITE 440 - MIDSLOPE TERRACE}

A thick section of Pleistocene to upper Miocene diatomaceous ooze and diatomaceous claystone was recovered from three holes drilled at Site 440 on the midslope terrace. The thick Pleistocene section at this site contrasts with the much thinner slope sequences cored by Legs 56 and 57 and suggests the possibility of sediment ponding.

Diatoms and radiolarians provide excellent biostratigraphic control throughout the section (Figure 8). Calcareous nannofossils and planktonic foraminifers offer generally good control, but they occur sporadically, especially in the lower part of the section. Diatoms sug- 


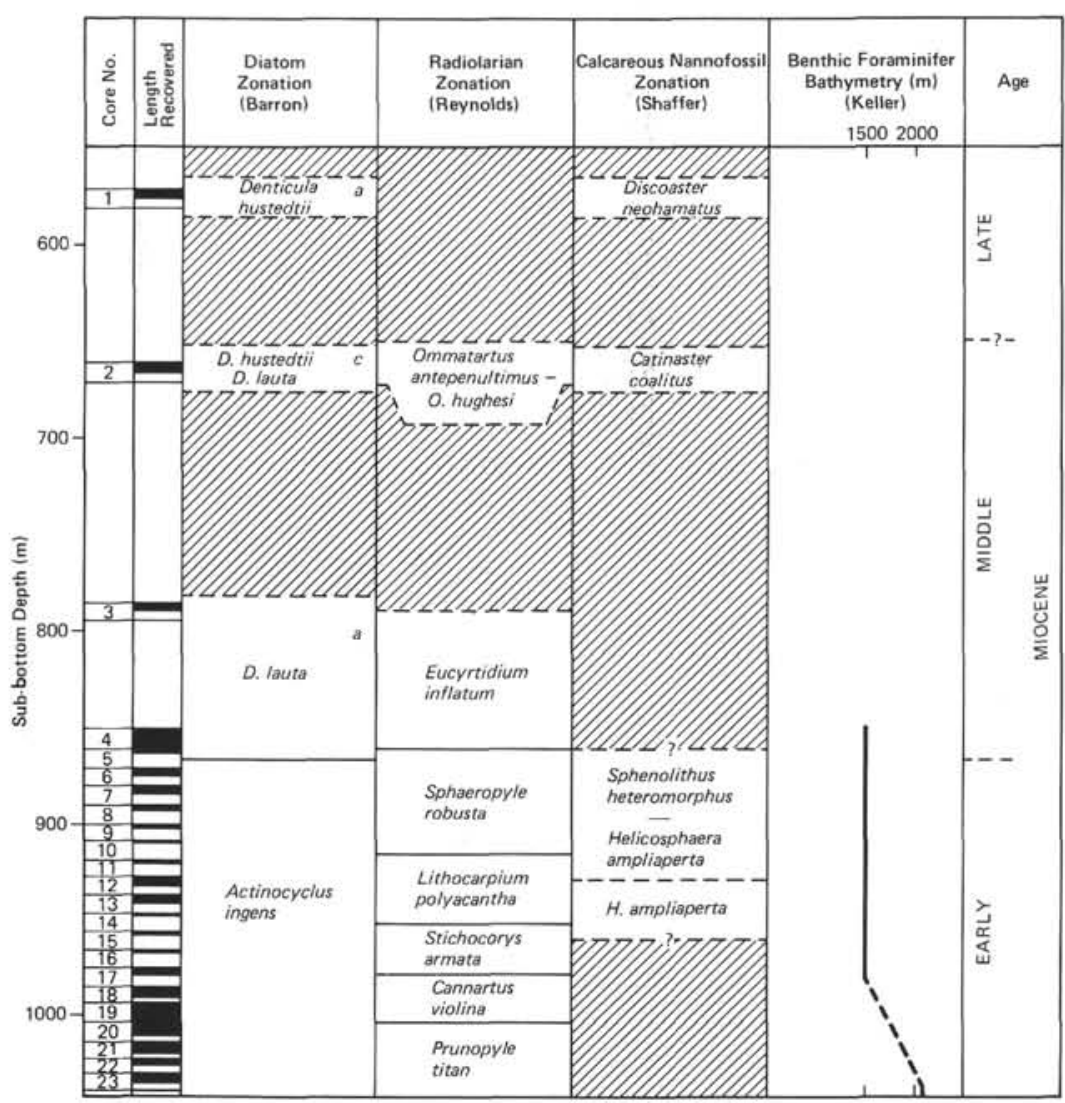

Figure 5. Planktonic microfossil biostratigraphy and generalized paleobathymetry of Site 438, Hole 438B. (Solid area represents recovered intervals; cross-hatched area represents intervals that could not be zoned.)

gest that an upper Miocene hiatus, which is correlative with a hiatus at Site 438 , is present at about 650 meters (Barron, this volume). Radiolarians and calcareous nannofossils give no evidence of this hiatus.

The excellent biostratigraphic control at Site 440 is supplemented by the paleomagnetic studies of Hall and others (this volume). They place the Brunhes/Matuyama Epoch boundary at 155 meters, the top of the Olduvai Event at 310 meters, the Gilbert/Gauss Epoch boundary at 495 meters, and the Gilbert/Epoch 5 boundary at 680 meters. These results agree well with the correlations suggested by the microfossil biostratigraphy (Figure 1).

Benthic foraminifers indicate that depths remained at or below the CCD during the late Miocene to Recent at Site 440 .

\section{SITE 441 - LOWER SLOPE}

At Site 441 on the lower slope, Pleistocene to upper Miocene diatomaceous clays and diatomaceous claystones were recovered from three holes (Figure 9).

Site 441 presently lies well below the CCD (which is about $3500 \mathrm{~m}$ ) and probably has remained so since at least the late Miocene. Consequently planktonic foraminifers and calcareous nannofossils are extremely rare and poorly preserved. Diatoms and radiolarians provide almost all of the biostratigraphy at Site 441 , but both are sparse and poorly preserved below 500 meters. A hiatus (at about $5 \mathrm{~m}$ ) separates the thin uppermost Pleistocene interval from the thick upper Pliocene to upper Miocene sequence. Recovery is very poor, but a normal sequence of Pliocene to upper Miocene diatom and radiolarian zones is indicated. Highly brecciated sediment in the lower Pliocene to upper Miocene interval contains middle Miocene diatoms and radiolarians that are attributed to reworking caused by slumping of upslope sediment.

\section{SITE 434 - LOWER SLOPE}

Site 434 is the deepest site of the Japan Trench Transect, located on the lower inner slope, landward from the trench. A composite section of upper Miocene to Pleistocene diatomaceous clay and diatomaceous claystone was cored in Holes 434, 434A, and 434B (Figure 10).

Diatoms and radiolarians provide age control throughout the cored section; planktonic foraminifers allow age assignment only in scattered samples in the upper part of the section. The vertical distribution of agediagnostic diatoms and radiolarians is anomalous. The upper 54 meters is a normal sequence of progressively older microfossil datums. A hiatus at about $5 \mathrm{me}-$ ters separates uppermost Pleistocene sediments from 


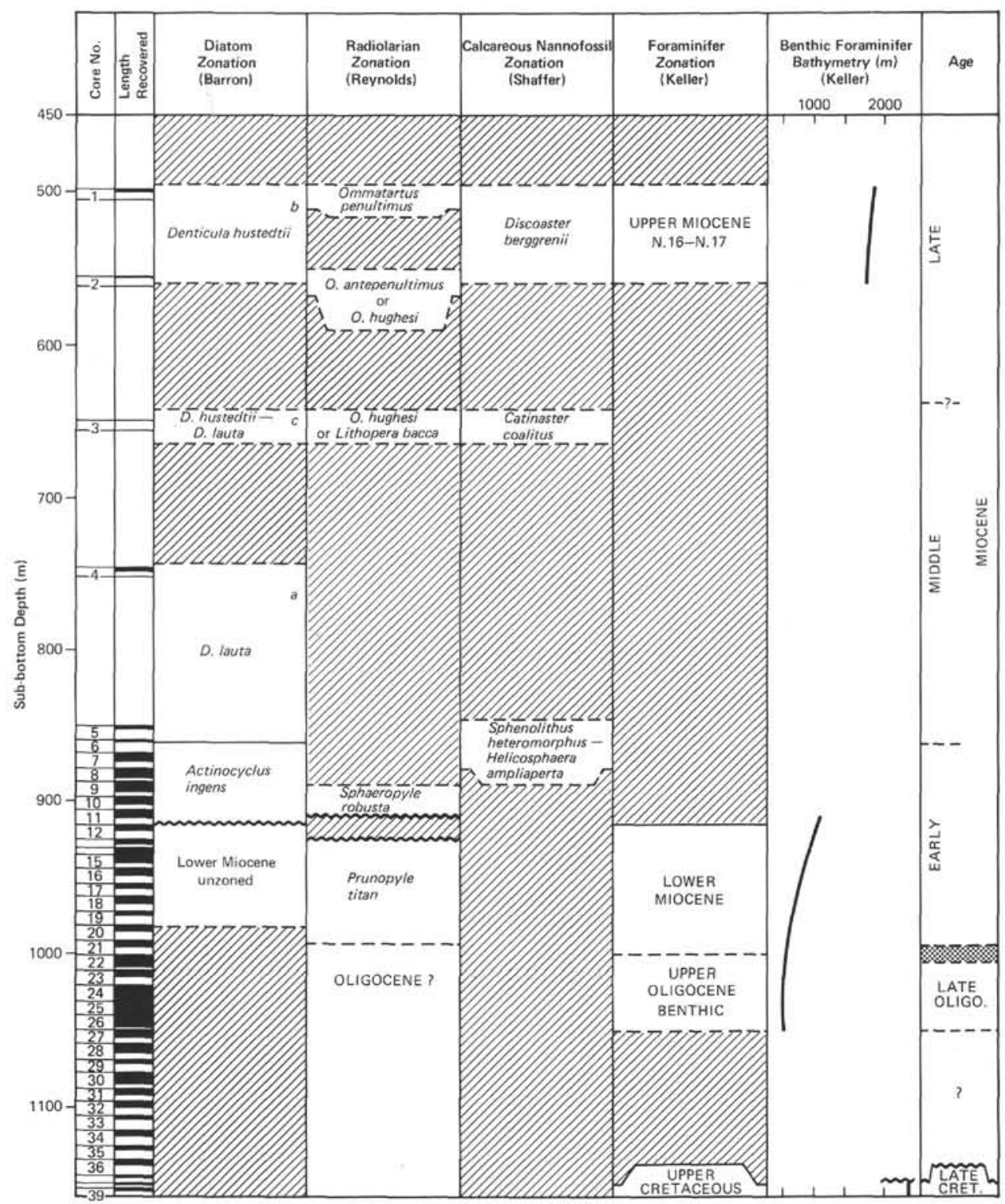

Figure 6. Microfossil biostratigraphy and generalized paleobathymetry of Site 439. (Solid area represents recovered intervals; cross-hatched area represents intervals that could not be zoned. The lower Miocene, upper Oligocene, and Upper Cretaceous are dated by benthic foraminifers.)

underlying uppermost Pliocene sediments. The middle and lower parts of the section are characterized by a repeated sequence of lower Pliocene to upper Miocene diatom marker taxa. This repetition occurs at least twice, from 158 to 253 meters and again from 300 to 609 meters. At the base of Hole 434B, from 609 to 620 meters, lower Pliocene diatoms and possible lower Pliocene radiolarians underlie upper Miocene assemblages. Benthic foraminifers are similar to those of the other sites landward of the trench and show no evidence of oceanic plate sediment. The general tectonic setting of Site 434, at the base of the landward wall of the Japan Trench, suggests that faulting or block slumping is the mechanism responsible for producing the repeated lower Pliocene and upper Miocene sections at Site 434.

\section{SITE 436 - OCEAN BASIN}

Site 436 was drilled seaward of the Japan Trench at a depth of 5205 meters. Nearly 400 meters of sediments was recovered at this site. These sediments consist of vitric diatomaceous clays $(0-250 \mathrm{~m})$ and claystones (250-360 m), a manganese-rich dark brown clay (360$378 \mathrm{~m})$, and a dark brown banded chert (378-397 m).

Siliceous microfossils are common and well preserved except in the lowermost cores (Figure 11). Calcareous fossils are absent because of calcium carbonate dissolution. Cores 1 through $39(0-360 \mathrm{~m})$ yielded an essentially complete middle Miocene to Pleistocene siliceous record. The middle Miocene through Paleogene is represented by about 18 meters of microfossil-poor pelagic 


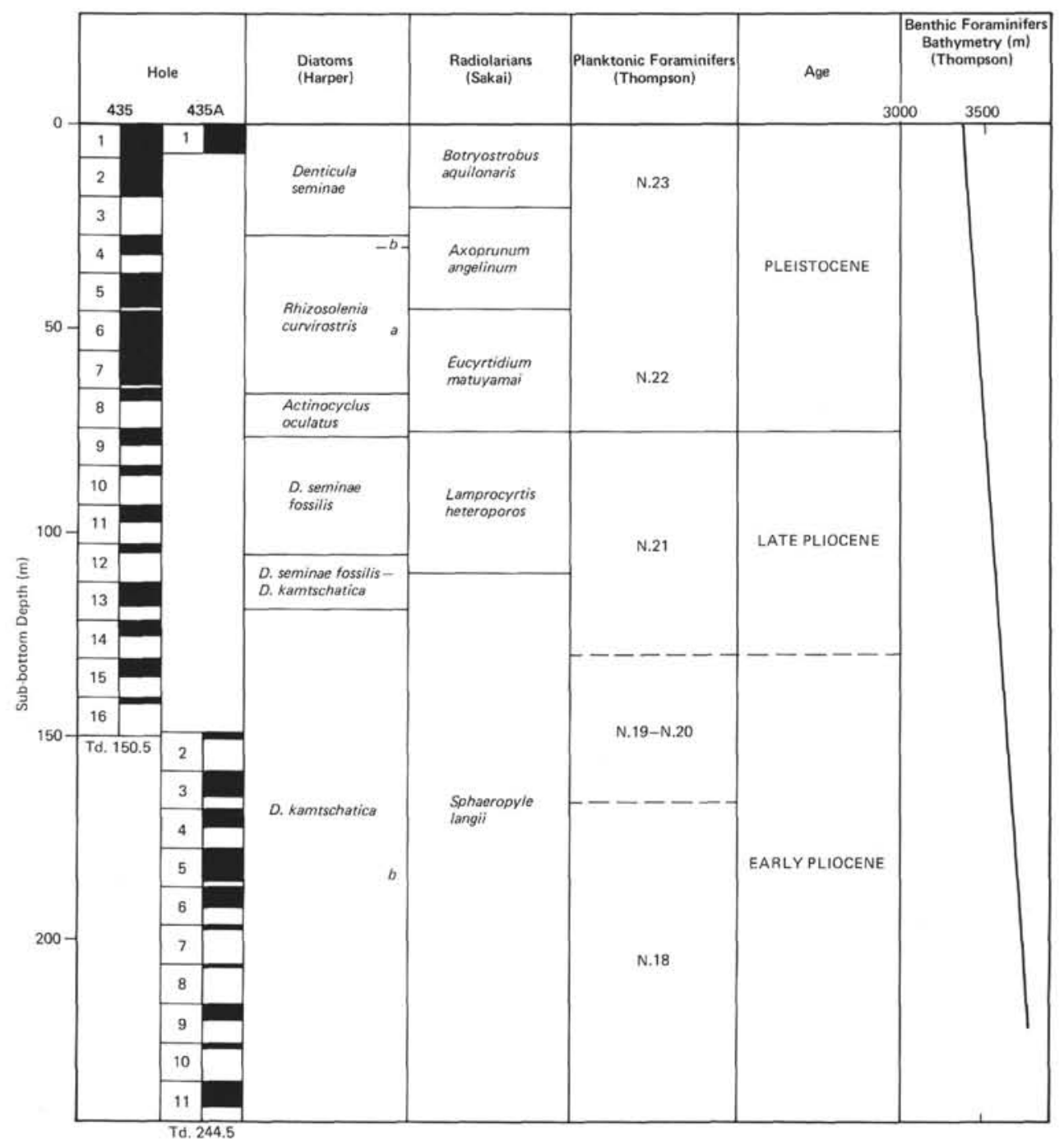

Figure 7. Planktonic microfossil biostratigraphy and generalized paleobathymetry of Site 435. (Solid area represents recovered intervals.)

clay $(360-378 \mathrm{~m})$. This section overlies a radiolarianrich chert of Early Cretaceous age (Figure 11).

Benthic foraminiferal faunas are different at generic and specific levels from assemblages at comparable depths on the landward slope and may be evidence that ocean plate sediments are being subducted without making any significant contribution to the landward slope.

\section{CORRELATION OF LEG 56 AND LEG 57 SITES}

The sites cored along the Japan Trench Transect are correlated by selected microfossil datum levels and by interpreted time-rock boundaries in Figure 12. The holes are arranged from east to west (landward to seaward), with the Japan Trench located between Sites 434 and 436 . Holes 438, 438A, 438B, and 439 form a composite reference section for the upper slope and include uppermost Oligocene to Recent sediments unconformably overlying an Upper Cretaceous black shale. Al- though Hole 438B and Hole 439 are located within 10 $\mathrm{km}$ of Hole 438A, Miocene microfossil datum levels lie 10 to 30 meters lower in these holes than they do in Hole 438A. The upper part of the section at Site 435 compares closely with that at Site 438 . Correlations, however, suggest thinning of the Pliocene section between Site 438 and Site 435 . At Site 440 , the Pleistocene is significantly thicker $(300 \mathrm{~m})$ than at any of the slope sites, suggesting that ponding of the Pleistocene sediments may have occurred. Sites 441 and 434, on the lower slope, contain similar sequences with thin uppermost Pleistocene sections unconformably overlying thick Pliocene to upper Miocene sections. Repetition of lower Pliocene and upper Miocene diatom zones at Site 434 suggests that faulting or block slumping may account for this thickening of the section. Seaward from the trench, the relatively thin section at Site 436 contrasts with the much thicker sections cored on the slope. 


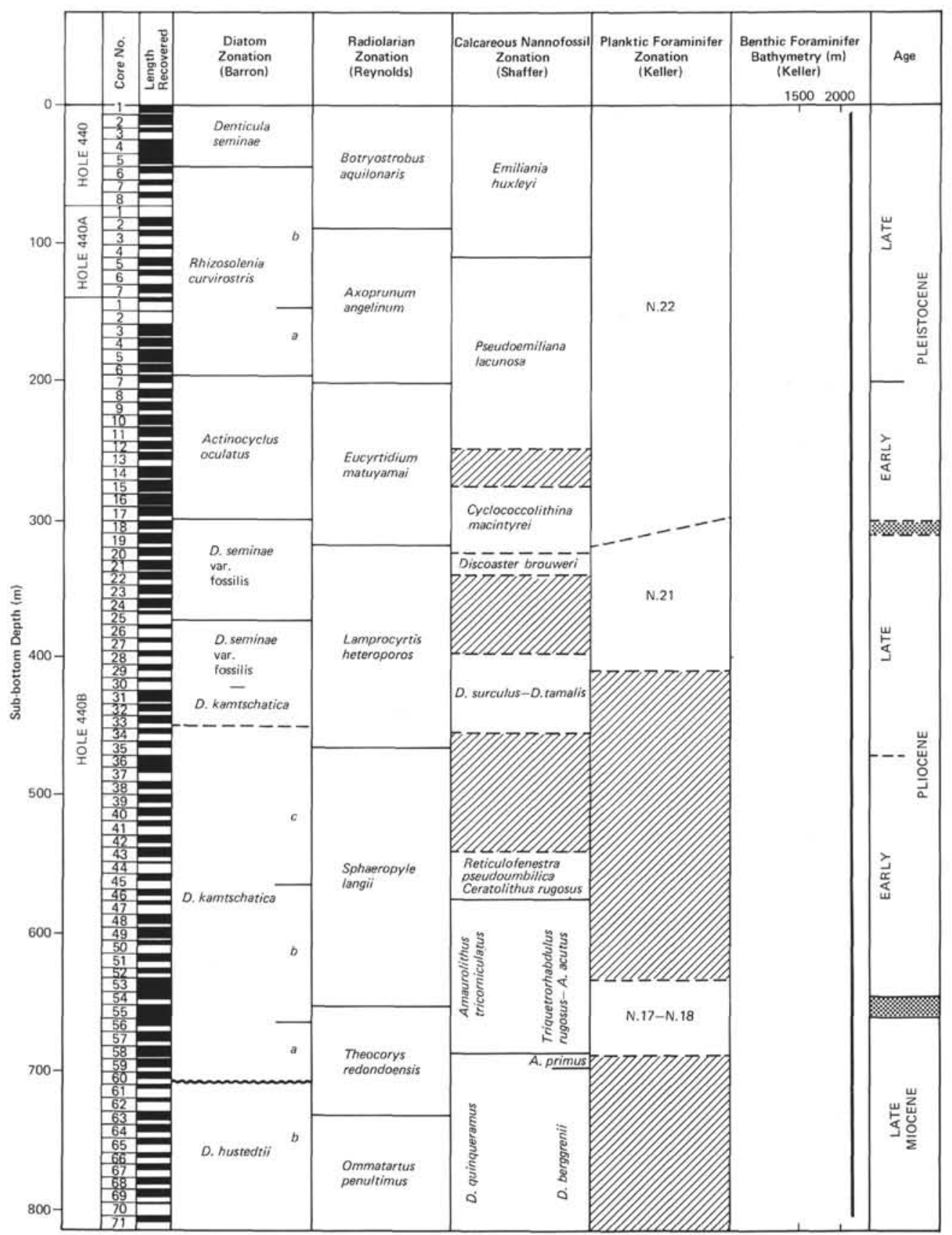

Figure 8. Planktonic microfossil biostratigraphy and generalized paleobathymetry of Site 440. (Solid area represents recovered intervals; cross-hatched area represents intervals that could not be zoned.)

\section{REFERENCES}

Blow, W. H., 1969. Late middle Eocene to Recent planktonic foraminiferal biostratigraphy. In Brönniman, P., and Renz, H. H. (Eds.), First International Conference on Planktonic Microfossils, Geneva, 1967 (Vol. 1): Leiden (E. J. Brill), 199-421.

Bukry, D., 1975. Coccolith and silicoflagellate stratigraphy, northwestern Pacific Ocean, Deep Sea Drilling Project Leg 32. In Larson, R. L., Moberly, R., et al., Init. Repts. $D S D P, 32$ : Washington (U.S. Govt. Printing Office), 677701.
Burckle, L. H., 1978. Early Miocene to Pliocene diatom datum levels for the equatorial Pacific. Geol. Soc. Indonesia Proc. IGCP Project 114 Meetings, Indonesia, 1977. Republic of Indonesia, Geological Research and Development Centre, Special Publication No. 1, pp. 25-44.

Burckle, L. H., and Opdyke, N. D., 1977. Late Neogene diatom correlations in the Circum-Pacific. Proceedings of the First International Congress on Pacific Neogene Stratigraphy: Tokyo (Kaiyo Shuppan), pp. 255-284.

Cita, M. B., 1975. The Miocene/Pliocene boundary: History and definition. In Saito, T., and Burckle, L. H. (Eds.), Late Neogene Epoch Boundaries: New York (Micropaleontology Press), pp. 1-30. 


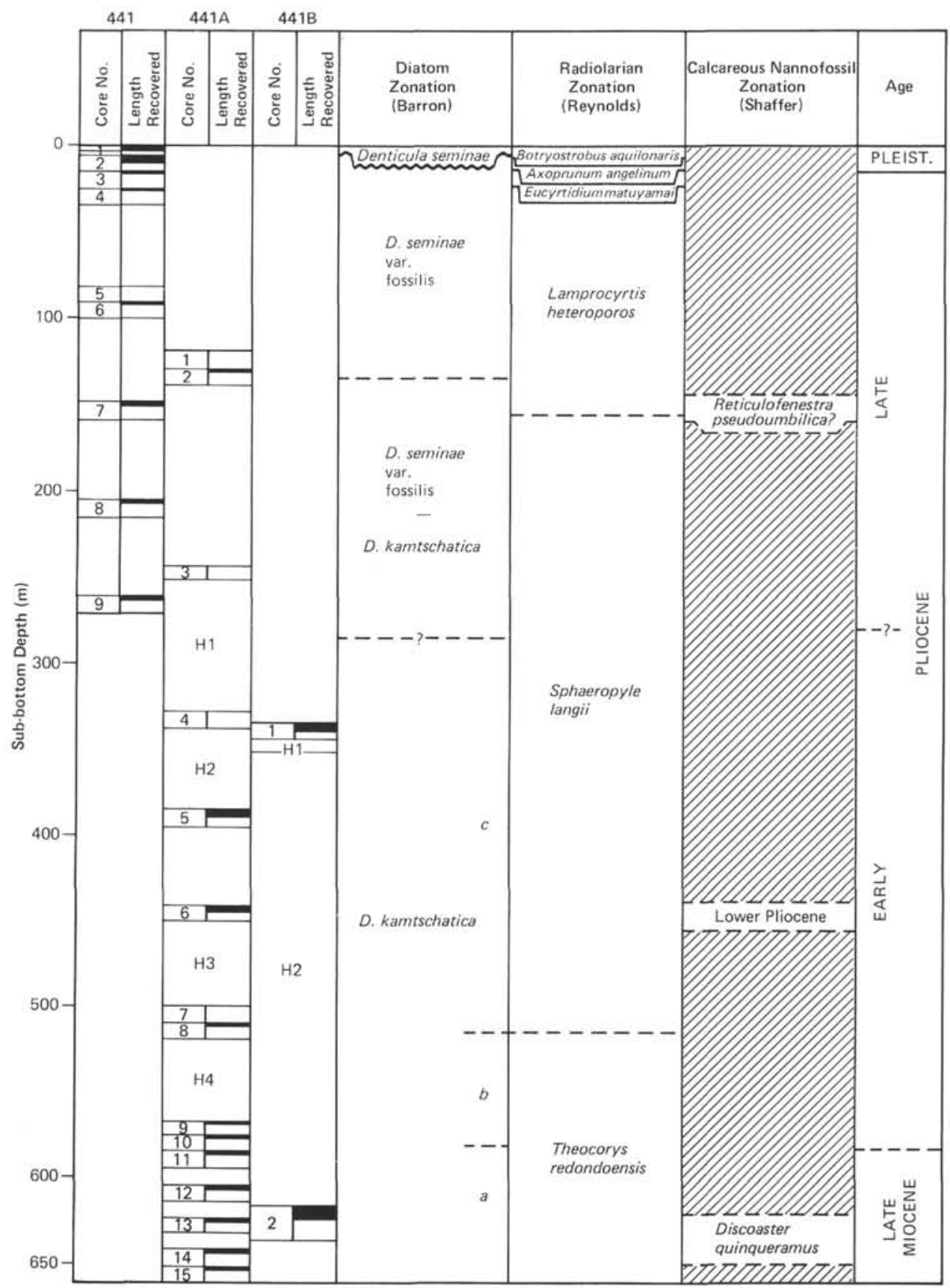

Figure 9. Planktonic microfossil biostratigraphy of Site 441. (Solid area represents recovered intervals; cross-hatched area represents intervals that could not be zoned.)

Foreman, H. P., 1975. Radiolaria from the North Pacific, Deep Sea Drilling Project Leg 32. In Larson, R. L., Moberly, R., et al., Init. Repts DSDP, 32: Washington (U.S. Govt. Printing Office), 579-676.

Gartner, S., 1973. Absolute chronology of the late Neogene calcareous nannofossil succession in the equatorial Pacific. Geol. Soc. Am. Bull., 84, 2021-2045.

1977. Calcareous nannofossil biostratigraphy and revised zonation of the Pleistocene. Mar. Micropaleont., 2, $1-25$.

Haq, B.-U., Berggren, W. A., and Van Couvering, J. A., 1977. Corrected age of the Pliocene-Pleistocene boundary. $\mathrm{Na}$ ture, 269, 483-488.
Hays, J. D., 1970. Stratigraphy and evolutionary trends of Radiolaria in North Pacific deep-sea sediments. Geol. Soc. Am. Mem., 126, 185-218.

Keller, G., 1978. Late Neogene biostratigraphy and paleoceanography of DSDP Site 310, central North Pacific and correlation with the southwest Pacific. Mar. Micropaleont. 3, 97-119.

1979. Early Pliocene to Pleistocene planktonic foraminiferal datum levels in the North Pacific: DSDP Sites 173, 310, and 296. Mar. Micropaleont., 4, 159-172.

Koizumi, I., 1975. Late Cenozoic diatom biostratigraphy in the circum-North Pacific. Geol. Soc. Japan J., 81 (No. 10), 611-627. 
1977. Diatom biostratigraphy in North Pacific region. Proceedings of the First International Congress on Pacific Neogene Stratigraphy: Tokyo (Kaiyo Shuppan), pp. 235-253.

LaBrecque, J. L., Kent, D. V., and Cande, S. C., 1977. Revised magnetic polarity time scale for Late Cretaceous and Cenozoic time. Geology, 5, 330-335.

Ryan, W. B. F., Cita, M. B., Rawson, M., Burckle, L. H., and Saito, T., 1974. A paleomagnetic assignment of Neogene stage boundaries and the development of isochronous datum planes between the Mediterranean, the Pacific and Indian
Ocean in order to investigate the response of the world ocean to the Mediterranean "salinity crisis." Riv. Ital. Paleontol., $80,631-688$.

Thompson, P. R., 1978. Late Tertiary planktonic foraminiferal datum biostratigraphy of the western North Pacific. Correlation of Tropical through High Latitude Marine Neogene Deposits of the Pacific Basin (Vol. XIV): Stanford, (Stanford University Press), 60-61. (Abstract)

Van Couvering, J. A., Berggren, W. A., Drake, R. F., Aguirre, F., and Curtis, G. H., 1976. The terminal Miocene event. Mar. Micropaleont., 1, 263-286. 


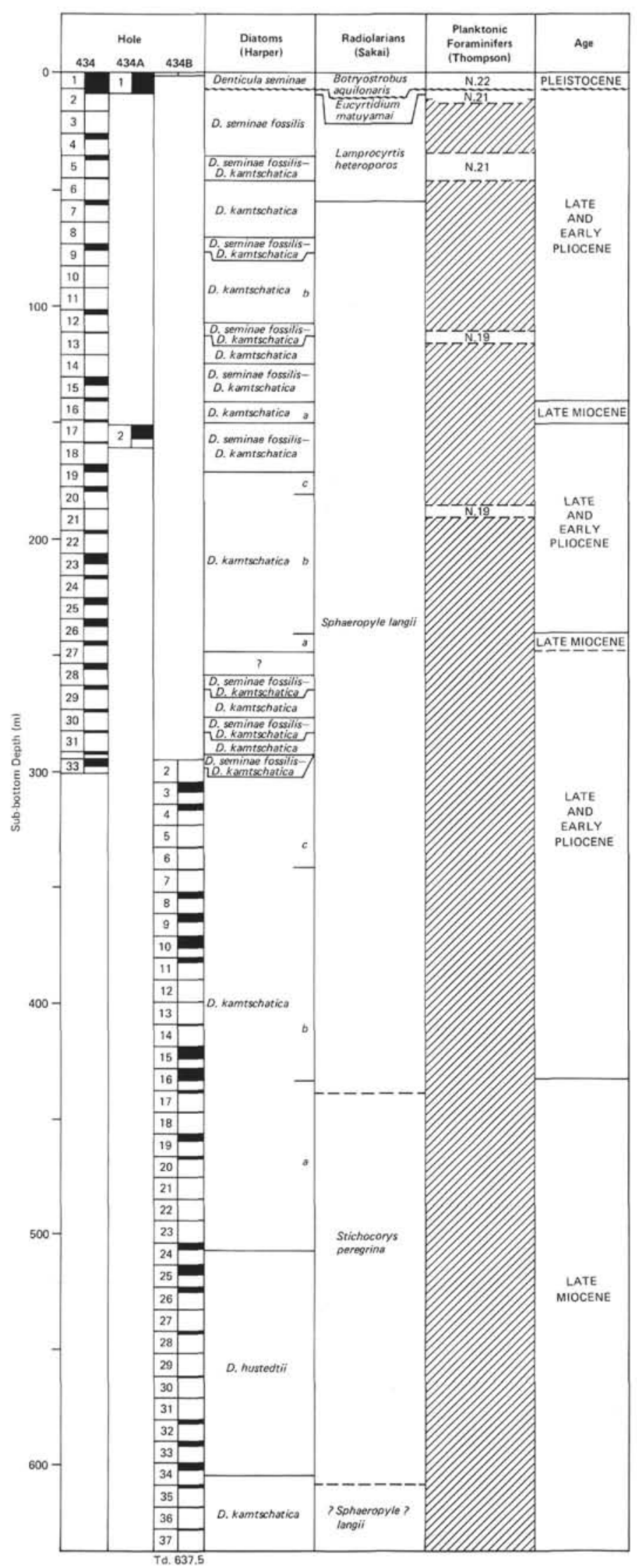

Figure 10. Planktonic microfossil biostratigraphy of Site 434. (Solid area represents recovered intervals; crosshatched area represents intervals that could not be zoned. Note repetition of diatom zones $[D K=$ Denticula kamtschatica Zone; $D s f-D K=$ Denticula seminae var. fossilis-Denticula kamtschatica Zone].) 


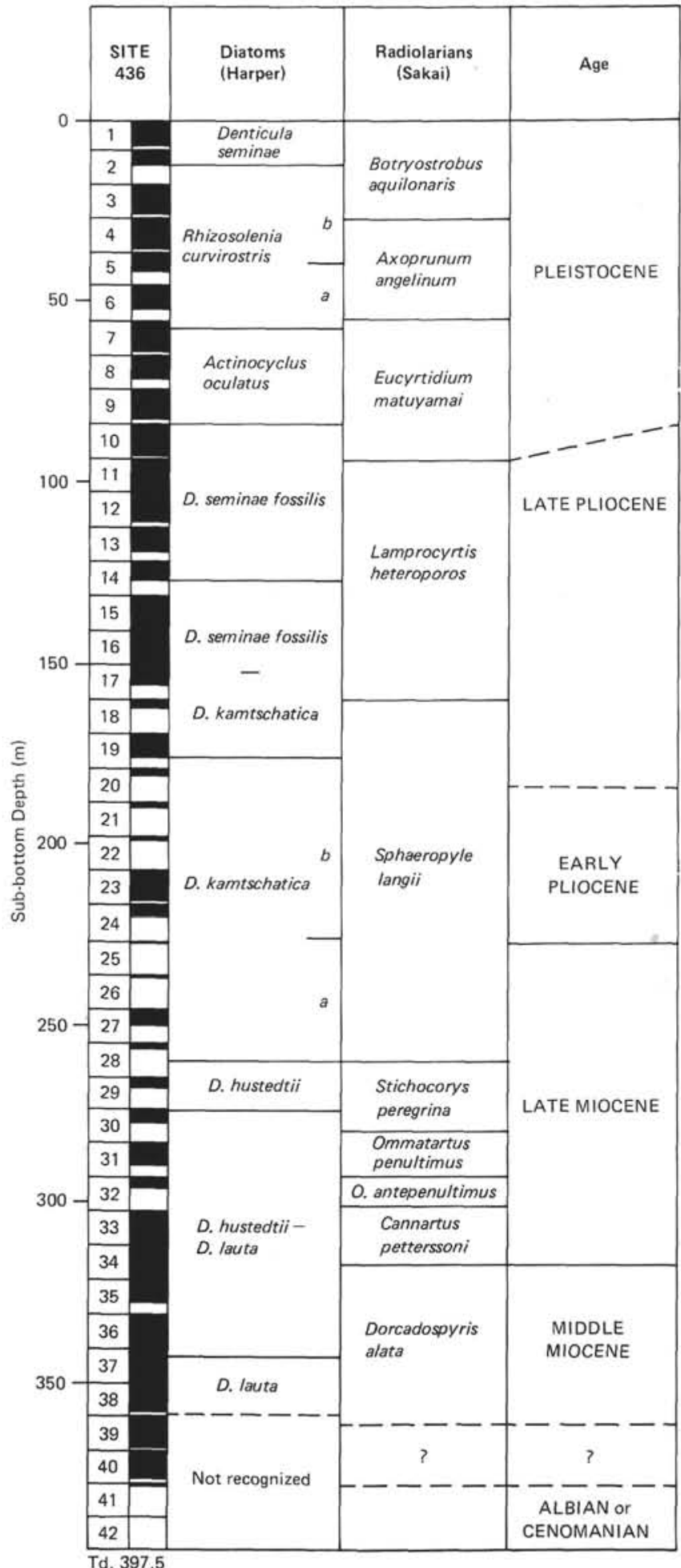

Figure 11. Planktonic microfossil biostratigraphy of Site 436. (Solid area represents recovered intervals; crosshatched area represents intervals that could not be zoned.) 


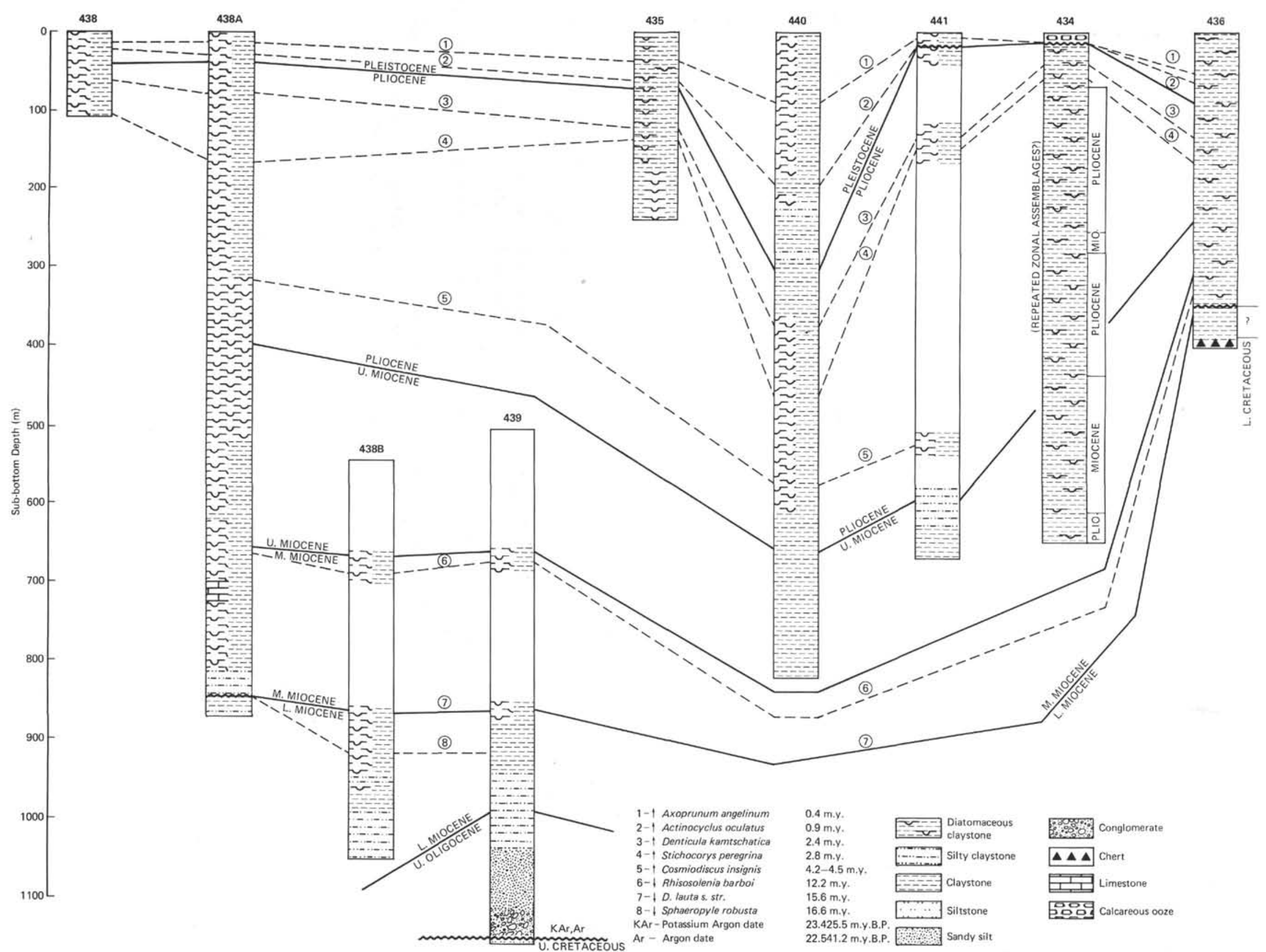

Figure 12. Correlation of the Japan Trench Transect sections (sites and holes) by selected microfossil datums and estimated epoch boundaries. 